\title{
Effect of allergen avoidance at high altitude on direct and indirect bronchial hyperresponsiveness and markers of inflammation in children with allergic asthma
}

Edwin van Velzen, Jan-W van den Bos, Jan A W Benckhuijsen, Truus van Essel, Richard de Bruijn, René Aalbers

\begin{abstract}
Background - Improvement of allergic asthma is seen at high altitude partly because of low concentrations of allergen, especially house dust mite. To investigate the effect of a hypoallergenic environment (Davos, $1560 \mathrm{~m}$ ) on airways inflammation, the changes in bronchial hyperresponsiveness measured with methacholine and adenosine 5'-monophosphate (AMP), blood eosinophils, eosinophil cationic protein (ECP), and serum IgE were studied. Methods - In 16 allergic asthmatic children tests were performed on admission and after one month. Medication was kept unchanged during the month of investigation and the patients performed peak expiratory flow (PEF) measurements twice daily.

Results - After one month at high altitude a considerable improvement was seen in the provocative concentration of AMP causing a $20 \%$ fall in forced expiratory volume in one second $\left(\mathbf{P C}_{20} \mathbf{A M P}\right)$, but not with methacholine. There was also a reduction in total blood eosinophils and ECP. No change in serum IgE was observed. Peak flow variability decreased. Conclusions - After one month at high altitude a reduction in airways inflammation occurs. The results indicate that AMP responsiveness is a more accurate marker of disease activity in relation to inflammation in asthma than methacholine. The benefits of allergen avoidance at high altitude have important clinical implications for children with allergic asthma.

(Thorax 1996;51:582-584)
\end{abstract}

Dutch Asthmacentre

Davos,

Symondsstrasse 11, CH-7270 Davos Platz, Switzerland

E van Velzen

$\mathrm{J}-\mathrm{W}$ van den Bos

J A W Benckhuijsen

$T$ van Essel

$R$ de Bruijn

$R$ Aalbers

Correspondence to: Dr R Aalbers.

Received 20 July 1995 Returned to authors

12 September 1995

Revised version received

6 December 1995

Accepted for publication

18 January 1996
Keywords: asthma, allergen avoidance, bronchial hyperresponsiveness.

For decades children and adults with allergic asthma have been sent to alpine climates where there are low concentrations of house dust mite in order to improve their asthma. ${ }^{12}$ Allergen avoidance often leads to a reduction in bronchial hyperresponsiveness ${ }^{2-4}$ and a rapid reduction in total blood eosinophils and eosinophil activation markers. ${ }^{4}$ Changes in total IgE only reach significance after a longer stay at high altitude. ${ }^{2}$ Bronchial hyperresponsiveness can be assessed by different stimuli; challenges with methacholine cause airway narrowing by direct action on airway smooth muscle, whereas stimuli such as adenosine $5^{\prime}$-monophosphate (AMP) are thought to act on "inflammatory" cells. ${ }^{5}$ No study has been performed to investigate the relation between changes in bronchial hyperresponsiveness provoked by methacholine and AMP after allergen avoidance.

The aim of our study was to investigate the effect of a hypoallergenic environment on airway inflammation measured by direct and indirect bronchial hyperresponsiveness, blood eosinophil counts, serum levels of eosinophil cationic protein (ECP), and total IgE in relation to peak expiratory flow rate (PEF) and forced expiratory volume in one second $\left(\mathrm{FEV}_{1}\right)$ in children with allergic asthma. In order to obtain reliable results, the medical treatment on admission was continued and kept unchanged during the month of investigation.

\section{Methods}

Sixteen children with allergic asthma as defined by the ATS $^{6}$ participated in the study. All came from The Netherlands and were admitted to the Dutch Asthmacentre between September 1993 and March 1994. Their characteristics are summarised in table 1 . At the time of admission they had been receiving regular antiinflammatory and bronchodilator drugs for many years and their medication was continued in the same doses as in The Netherlands. Exacerbations and viral infections did not occur during the first month so no adjustment of medication was necessary.

The morning after arrival blood samples were taken and lung function was measured. Methacholine challenge was performed on the second day after arrival and AMP provocation tests were done 72 hours later. After one month all the tests were performed again at the same time of the day and in the same order.

During the month of the study the children performed PEF twice daily using a mini-Wright peak flow meter and the best of three PEF manoeuvres was recorded. The variation in PEF was defined as the highest - the lowest value in a 24 hour period/the mean 24 hour value. The mean values of the first and the fifth week were used for the peak flow recordings.

The levels of bronchial hyperresponsiveness were evaluated by methacholine bromide and 
Table 1 Characteristics of patients

\begin{tabular}{|c|c|c|c|c|c|c|}
\hline $\begin{array}{l}\text { Patient } \\
\text { no. }\end{array}$ & Sex & Age & $\begin{array}{l}F E V_{1} \\
\text { (\%pred) }\end{array}$ & $\begin{array}{l}\text { CAP-House } \\
\text { dust mite } \\
(k U / l)\end{array}$ & $\begin{array}{l}\text { Inhaled } \\
\text { corticosteroids } \\
(\mu g)\end{array}$ & Medication \\
\hline $\begin{array}{l}1 \\
2 \\
3 \\
4 \\
5 \\
6 \\
7 \\
8 \\
9 \\
10 \\
11 \\
12 \\
13 \\
14 \\
15 \\
16 \\
\text { Mean (SE) }\end{array}$ & $\begin{array}{l}\mathrm{F} \\
\mathrm{F} \\
\mathrm{F} \\
\mathrm{F} \\
\mathrm{M} \\
\mathrm{M} \\
\mathrm{M} \\
\mathrm{F} \\
\mathrm{M} \\
\mathrm{M} \\
\mathrm{F} \\
\mathrm{M} \\
\mathrm{F} \\
\mathrm{F} \\
\mathrm{F} \\
\mathrm{F}\end{array}$ & $\begin{array}{l}14 \\
13 \cdot 5 \\
17 \\
15 \\
18 \\
16 \\
13 \\
14 \\
15 \\
15 \cdot 5 \\
11 \\
10 \cdot 5 \\
15 \cdot 5 \\
13 \\
13 \cdot 5 \\
18 \cdot 5 \\
14 \cdot 6(0 \cdot 2)\end{array}$ & $\begin{array}{l}114 \\
97 \cdot 1 \\
114 \\
127 \\
89 \cdot 5 \\
89 \cdot 7 \\
83 \cdot 4 \\
97 \cdot 5 \\
41 \cdot 5 \\
74 \cdot 3 \\
73 \cdot 1 \\
62 \cdot 3 \\
128 \\
103 \\
101 \\
77 \cdot 7 \\
94 \cdot 2(5 \cdot 5)\end{array}$ & $\begin{array}{c}24 \cdot 6 \\
0 \cdot 89 \\
33 \cdot 2 \\
65 \cdot 2 \\
59 \cdot 4 \\
65 \cdot 7 \\
35 \cdot 5 \\
59 \cdot 6 \\
66 \cdot 6 \\
>100 \\
92 \cdot 3 \\
>100 \\
5 \cdot 08 \\
97 \cdot 6 \\
34 \cdot 2 \\
1 \cdot 02 \\
46 \cdot 7(8 \cdot 7)\end{array}$ & $\begin{array}{r}400 \\
1200 \\
800 \\
800 \\
800 \\
800 \\
400 \\
800 \\
800 \\
1200 \\
400 \\
800 \\
600 \\
1000 \\
800 \\
2400 \\
1388 \cdot 9(517 \cdot 5)\end{array}$ & $\begin{array}{l}\beta, \mathrm{L} \beta \\
\beta, \mathrm{L} \beta, \mathrm{OS} \\
\mathrm{IB} \\
\mathrm{IB}, \mathrm{C}, \mathrm{A} \\
\beta, \mathrm{C}, \mathrm{A} \\
\mathrm{IB} \\
\mathrm{IB} \\
\beta, \mathrm{L} \beta, \mathrm{IB} \\
\beta, \mathrm{L} \beta \\
\beta, \mathrm{L} \beta \\
\beta \\
\beta, \mathrm{L} \beta \\
- \\
\mathrm{L} \beta, \mathrm{A} \\
\beta, \mathrm{L} \beta, \mathrm{IB}, \mathrm{A} \\
\beta, \mathrm{L} \beta, \mathrm{IB}, \mathrm{T}\end{array}$ \\
\hline
\end{tabular}

$\beta=$ short acting sympathicomimetics; $\mathrm{L} \beta=$ long acting sympathicomimetics; $\mathrm{OS}=$ oral steroids; $\mathrm{IB}=$ ipratropium bromide; $\mathrm{C}=$ inhaled cromoglycate; $\mathrm{A}=$ antihistamines; $\mathrm{T}=$ oral theophylline.

AMP challenge. Increasing doubling dose concentrations of methacholine (from 0.03 to $16 \mathrm{mg} / \mathrm{ml}$ ) and AMP (from $0 \cdot 15$ to $320 \mathrm{mg} / \mathrm{ml}$ ) were delivered by a DeVilbiss 646 nebuliser. The nebuliser output was $0.13 \mathrm{ml} / \mathrm{min}$ and the duration of the inhalation was two minutes. $\mathrm{FEV}_{1}$ was evaluated by a Masterlab pneumotachograph (Jaeger; Würzburg, Germany), and the concentration causing a $20 \%$ decrease in $\mathrm{FEV}_{1}$ values $\left(\mathrm{PC}_{20} \mathrm{FEV}_{1}\right)$ was derived by standard means. ${ }^{7}$

Before the challenge xanthine derivatives and sodium cromoglycate were withheld for 48 hours, long acting and short acting $\beta_{2}$ agonists for 24 and six hours, respectively, antihistamines for 72 hours, and anticholinergics for six hours.

Blood was centrifuged at $4000 \mathrm{rpm}$ for 10 minutes at room temperature and serum was immediately frozen and stored at $-20^{\circ} \mathrm{C}$ until the assays were performed. Total IgE and ECP levels were measured by fluorescence enzyme immunoassay (CAP System; Pharmacia, Uppsala, Sweden) as described earlier and exactly according to the guidelines supplied by the manufacturer. $^{8}$

Blood eosinophils expressed as total $/ \mathrm{mm}^{3}$ were determined on May Grünwald-Giemsa stained smears obtained from the same blood samples as serum. Counting of 500 cells was always performed by the same person (TvE).
The study was approved by the local hospital ethical committee and all children's parents gave written informed consent.

\section{DATA ANALYSIS}

$\mathrm{PC}_{20}$ values were analysed after base 2 logarithmic transformation, and eosinophil, serum ECP, and IgE counts were performed after 10 logarithmic transformation. Changes in the parameters were analysed using the Student's $t$ test. Spearman's rank correlations were performed.

\section{Results}

All 16 patients completed the study. Comparison of mean (SE) baseline percentage predicted $\mathrm{FEV}_{1}$ showed no improvement from a mean of $92 \cdot 1(5 \cdot 8) \%$ to $97 \cdot 0(5 \cdot 1) \%$. However, peak flow variability improved from a mean value of $12 \cdot 1(2 \cdot 5) \%$ to $7 \cdot 2(1 \cdot 2) \%(p<0 \cdot 01)$.

After one month at high altitude no improvement in responsiveness to methacholine was observed from a geometric mean of 0.48 $(0.56) \mathrm{mg} / \mathrm{ml}$ to $0.62(0.77) \mathrm{mg} / \mathrm{ml}$. In contrast, a marked decrease in AMP responsiveness from $6 \cdot 21(26 \cdot 72) \mathrm{mg} / \mathrm{ml}$ to $25 \cdot 78(25 \cdot 6) \mathrm{mg} / \mathrm{ml} \mathrm{(p=}$ $0.001 ; 95 \%$ confidence interval $(\mathrm{CI})-3 \cdot 14$ to $-0.962)$ was seen with $2 \cdot 1$ doubling doses (table 2).

Table 2 Bronchial hyperresponsiveness to methacholine and AMP in $\mathrm{mg} / \mathrm{ml}$ at the start of the study and after one month at high altitude

\begin{tabular}{|c|c|c|c|c|}
\hline \multirow[t]{2}{*}{ Patient no. } & \multicolumn{2}{|c|}{$P C_{20}$ methacholine } & \multicolumn{2}{|l|}{$P C_{20} A M P$} \\
\hline & Admission & 1 month & Admission & 1 month \\
\hline 1 & $0 \cdot 21$ & $0 \cdot 47$ & $0 \cdot 38$ & $18 \cdot 10$ \\
\hline 2 & $0 \cdot 24$ & 0.54 & 0.59 & $8 \cdot 35$ \\
\hline 3 & $0 \cdot 28$ & 0.60 & $7 \cdot 58$ & $30 \cdot 80$ \\
\hline 4 & $9 \cdot 10$ & $12 \cdot 66$ & $320 \cdot 00$ & $320 \cdot 00$ \\
\hline 5 & 0.29 & 0.43 & 3.03 & $\begin{array}{r}520.00 \\
51.90\end{array}$ \\
\hline 6 & 0.38 & $2 \cdot 14$ & $13 \cdot 20$ & $13 \cdot 80$ \\
\hline 7 & $0 \cdot 19$ & $0 \cdot 10$ & $3 \cdot 15$ & $28 \cdot 80$ \\
\hline 8 & $2 \cdot 22$ & 0.66 & 4.76 & 23.00 \\
\hline 9 & 0.13 & 0.31 & 0.91 & $46 \cdot 70$ \\
\hline 10 & 0.48 & 0.25 & $20 \cdot 00$ & 20.00 \\
\hline 11 & $0 \cdot 15$ & $0 \cdot 24$ & 0.88 & $7 \cdot 43$ \\
\hline 12 & $0 \cdot 28$ & $0 \cdot 18$ & $1 \cdot 15$ & 2.95 \\
\hline 13 & 1.90 & $2 \cdot 40$ & 320.00 & $320 \cdot 00$ \\
\hline 14 & 0.51 & 0.53 & $28 \cdot 30$ & $16 \cdot 20$ \\
\hline 15 & $1 \cdot 70$ & 2.02 & $34 \cdot 20$ & $50 \cdot 40$ \\
\hline 16 & 0.31 & 0.48 & $2 \cdot 65$ & 10.00 \\
\hline Geometric mean(SE) & $0.48(0.56)$ & $0.62(0 \cdot 77)$ & $6 \cdot 21(26 \cdot 72)$ & $25 \cdot 78(25 \cdot 6)$ \\
\hline
\end{tabular}


The geometric mean (SE) number of eosinophils decreased from $372.39(87.04) / \mathrm{mm}^{3}$ to $233.35(67 \cdot 83) / \mathrm{mm}^{3}$ (p<0.01; 95\% CI 0.060 to 0.346$)$. Serum ECP levels also showed a reduction from $15.24(5 \cdot 42) \mu \mathrm{g} / \mathrm{l}$ to $8.97(2 \cdot 19)$ $(\mathrm{p}<0.05)$, but no change was seen in total $\mathrm{IgE}$ levels (from $961.61(512 \cdot 82 \mathrm{kU} / 1$ to $957 \cdot 19$ $(475 \cdot 66) \mathrm{kU} / \mathrm{l})$.

No correlation could be observed between the changes in bronchial hyperresponsiveness measured with AMP and methacholine and the changes in eosinophils, ECP, serum IgE, and peak flow variability.

\section{Discussion}

In this group of children we were able to show that, after one month in an environment free from the house dust mite, an improvement in bronchial hyperresponsiveness measured with AMP but not with methacholine is found. In addition, a reduction in total eosinophils and ECP was observed during this period, together with a beneficial effect in PEF variability. Our findings concerning ECP and eosinophils are supported by those of Boner et $a l^{4}$ who also observed a reduction in serum IgE after three months of allergen avoidance. Although serum IgE has a relatively short half life, we did not observe any change in IgE levels after one month. One possible explanation for this is that the children had undergone a high level of exposure to the allergen before the start of the study which caused a latent increase in $\operatorname{IgE}$ levels during the early part of the investigation, since all children were admitted in the winter season. Boner et al did not observe a relationship between bronchial hyperresponsiveness and any of the blood measurements at high altitude ${ }^{4}$ and nor did we. That no correlation between the change in PEF variability and ECP was seen in our study can be explained by the fact that the ECP levels were within the normal range, probably caused by the steroid medication. $^{8}$

Convincing evidence of an association between allergen load and bronchial hyperresponsiveness in asthma is shown by the worsening bronchial hyperresponsiveness after allergen challenge ${ }^{3}$ and the improvement, especially in indirect bronchial hyperresponsiveness as shown in this study, when a patient is moved to an allergen free environment. The large change in AMP responsiveness but not in methacholine responsiveness is intriguing in this respect and indicates the heterogeneity of bronchial provocation tests as shown in previous studies. ${ }^{3910}$ The large reduction in AMP responsiveness may indicate a reduction in mast cell numbers or a reduction in mast cell responsiveness to AMP, or a reduction in the target tissue response to the mediators as a result of allergen avoidance. The latter seems unlikely because of the relative stability of the methacholine response. It is known that corticosteroids reduce responsiveness to AMP more than to other stimuli. This AMP responsiveness seems to be a sensitive marker for the underlying inflammation in asthma. Allergen avoidance may have the same or even a better and more rapid effect on AMP responsiveness, as demonstrated in this study. One could argue that the medication taken during the study may have influenced the results. However, since all medication was kept unchanged, it suggests that the changes observed were a consequence of allergen avoidance.

The results of this study confirm that a stay at high altitude reduces airway inflammation in patients with asthma and indicate that AMP is a more accurate marker of disease activity in relation to inflammation than methacholine. Allergen avoidance at high altitude has important clinical implications for children with allergic asthma.

1 Spieksma FTM, Zuidema P, Leupen HJ. High altitude and house dust mites. BMF 1971;1:82-4.

2 Peroni DG, Boner AL, Vallone G, Antolini I, Warner JO. Effective allergen avoidance at high altitude reduces allergen-induced bronchial hyperresponsiveness. Am $\mathcal{f}$ Respir Crit Care Med 1994;149:1442-6.

3 Platts-Mills TAE, Tovey ER, Mitchell EB, Moszoro $\mathrm{H}$ Nock P, Wilkins SR. Reduction of bronchial hyper-
Notts-Mills TAE, Tovey ER, Mitchell EB, Moszoro H, reactivity during prolonged allergen avoidance. Lance 1982;ii:675-8.

4 Boner AL, Peroni DG, Piacentini GL, Venge P. Influence of allergen avoidance at high altitude on serum markers of eosinophil activation in children with allergic asthma. Clin Exp Allergy 1993;23:1021-6.

5 Aalbers R, Kauffman HF, Koëter GH, Postma DS, de Monchy JGR, deVries K. Dissimilarity in methacholine and AMP responsiveness 3 and 24 hours after allergen challenge. Am Rev Respir Dis 1991;144:312-7.

6 American Thoracic Society: Standards for the diagnosis and care of patients with chronic obstructive pulmonary disease

7 Sterk PJ, Fabri LM, Quanjer PhH, Cockcroft DW, O'Byrne PM, Anderson SD, et al. Airway responsiveness: standardized challenge testing with pharmacological, physica and sensitizing stimuli in adults. Eur Respir f 1993;6(Supp 16):53-83.

8 Midander $\mathrm{J}$. Clinical documentation of inflammation markers in asthma. Clin Exp Allergy 1993;23(Suppl 2): 13-14.

9 O'Connor BJ, Ridge SM, Barnes PJ, Fuller RW. Greater effect of inhaled budesonide on adenosine 5'-monophosphate-induced than on sodium-metabisulfite-induced bronchoconstriction in asthma. Am Rev Respir Dis 1992; 146:560-4.

10 Avital A, Springer C, Bar-Yishay E, Godfrey S. Adenosine methacholine and exercise challenges in children with asthma or pediatric chronic obstructive pulmonary disease. Thorax 1995;50:511-6. 